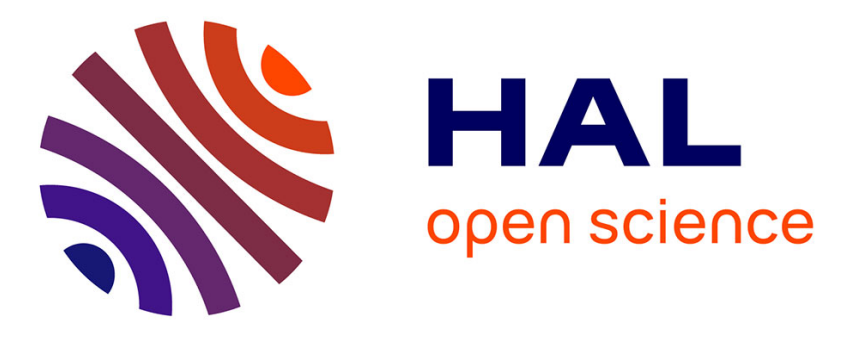

\title{
Pliocene river capture and incision of the northern Altiplano: Machu Picchu, Peru
}

Benjamin Gérard, Laurence Audin, Xavier Robert, Cécile Gautheron, Peter van Der Beek, Matthias Bernet, Carlos Benavente, Fabrizio Delgado

\section{- To cite this version:}

Benjamin Gérard, Laurence Audin, Xavier Robert, Cécile Gautheron, Peter van Der Beek, et al.. Pliocene river capture and incision of the northern Altiplano: Machu Picchu, Peru. Journal of the Geological Society, 2021, 178 (2), pp.jgs2020-100. 10.1144/jgs2020-100 . hal-03470137

\section{HAL Id: hal-03470137 https://hal.science/hal-03470137}

Submitted on 8 Dec 2021

HAL is a multi-disciplinary open access archive for the deposit and dissemination of scientific research documents, whether they are published or not. The documents may come from teaching and research institutions in France or abroad, or from public or private research centers.
L'archive ouverte pluridisciplinaire HAL, est destinée au dépôt et à la diffusion de documents scientifiques de niveau recherche, publiés ou non, émanant des établissements d'enseignement et de recherche français ou étrangers, des laboratoires publics ou privés. 


\title{
Pliocene river capture and incision of the northern Altiplano: Machu Picchu, Peru
}

\author{
Benjamin Gérard ${ }^{\text {*, Laurence Audin }}$, Xavier Robert ${ }^{1}$, Cécile Gautheron ${ }^{2}$, \\ Peter van der Beek ${ }^{1,3}$, Matthias Bernet ${ }^{1}$, Carlos Benavente ${ }^{4,5}$ and Fabrizio Delgado ${ }^{4,5}$ \\ ${ }^{1}$ Université Grenoble Alpes, Université Savoie Mont Blanc, CNRS, IRD, IFSTTAR, ISTerre, 38000 Grenoble, France \\ ${ }^{2}$ Université Paris-Saclay, CNRS, GEOPS, 91405 , Orsay, France \\ ${ }^{3}$ Institut für Geowissenschaften, Universität Potsdam, 14476 Potsdam, Germany \\ ${ }^{4}$ INGEMMET, Instituto Geológico, Minero y Metalúrgico, Lima, Perú \\ ${ }^{5}$ Facultad de Ciencias e Ingeniería, Pontificia Universidad Católica del Perú, Lima, Perú \\ (D) $\mathrm{BG}, 0000-0001-8143-8343$; LA, 0000-0002-4510-479X; XR, 0000-0002-0567-7497; CG, 0000-0001-7068-9868; \\ PvdB, 0000-0001-9581-3159; MB, 0000-0001-5046-7520; CB, 0000-0002-2237-0016; FD, 0000-0003-2029-0191 \\ Present address: BG, GET, Université de Toulouse, CNRS, IRD, UPS, (Toulouse), France \\ *Correspondence: benjamin.gerard.alpes@gmail.com
}

\begin{abstract}
The Abancay Deflection, forming the northern edge of the Altiplano in the Peruvian Andes, is a remarkable geomorphological feature marking the along-strike segmentation of the Andes. Little is known about the timing and spatial distribution of exhumation in this area. To constrain the exhumation history of the Abancay Deflection and its drivers, we present apatite $(\mathrm{U}-\mathrm{Th}) / \mathrm{He}$ and fission-track thermochronology data from samples collected along an elevation transect at Machu Picchu. Geomorphological analysis demonstrates recent and continuing drainage reorganization recorded by the spatial distribution of the normalized steepness index $\left(k_{\mathrm{sn}}\right)$ and normalized integrated drainage area $(\chi)$ parameters. Thermochronologically derived cooling rates are converted into exhumation using regionally constrained geothermal gradients between 16 and $26^{\circ} \mathrm{C} \mathrm{km}^{-1}$. Time-temperature inversions imply steady and slow exhumation $\left(<0.05 \mathrm{~km} \mathrm{Ma}^{-1}\right)$ between 20 and $4 \mathrm{Ma}$, followed by rapid exhumation $\left(>0.9 \mathrm{~km} \mathrm{Ma}^{-1}\right)$ since $4 \mathrm{Ma}$. The timing of rapid exhumation, combined with the geomorphological analysis, suggests that fluvial capture of the previously endorheic Altiplano by the Urubamba River drove recent incision and exhumation. Depending on the value of the geothermal gradient used, total exhumation since $4 \mathrm{Ma}$ can be explained by river incision alone or requires additional exhumation driven by tectonics, possibly associated with movement on the Apurimac fault.
\end{abstract}

Supplementary material: Additional information is available at https://doi.org/10.6084/m9.figshare.c.5177343

Received 26 May 2020; revised 16 September 2020; accepted 15 October 2020

The Central Andes contain the second-highest and -widest plateau on Earth: the Altiplano. Topographic building-up of the Andes has occurred since at least the Cretaceous (c. 120-110 Ma; Jaillard and Soler 1996); the northern Altiplano acquired its modern elevation during the Miocene (Barnes and Ehlers 2009; Garzione et al. 2017; Schildgen and Hoke 2018). Tectonic, climatic and erosional interactions affecting the Altiplano and its eastward border, the Eastern Cordillera (Fig. 1), have been extensively studied in the southern Central Andes of Bolivia and Argentina (e.g. Strecker et al. 2007). Pliocene canyon incision, potentially induced by global climate cooling, has been inferred for the Eastern Cordillera in southernmost Peru (Lease and Ehlers 2013). In contrast, the evolution of the northern edge of the Altiplano and the Eastern Cordillera further north in Peru remains poorly documented. This area is formed by the Abancay Deflection (Fig. 1; Dalmayrac et al. 1980), a major Andean transition zone that separates the wide Bolivian orocline (Central Andes) to the south from the narrower Northern Andes to the north. The Abancay Deflection has higher $(c .0 .3 \mathrm{~km})$ average elevation and is much more incised than the low-relief and internally drained Altiplano to the south (Fig. 1c). Palaeoaltimetry data (Picard et al. 2008; Sundell et al. 2019) and biodiversity records (Hoorn et al. 2010) suggest that the study area acquired its modern elevation of $c$. $4 \mathrm{~km}$ before $5 \mathrm{Ma}$. At the scale of the Central Andes, different potential uplift mechanisms have been proposed, including crustal shortening (Barnes and Ehlers 2009), lithospheric delamination (Garzione et al. 2006) and crustal flow (Husson and Sempere 2003; for a review see Garzione et al. 2017). Tectonic shortening was transferred from the Altiplano to the Subandes of central Peru during the mid- to late Miocene (Horton 2005; McQuarrie et al. 2005; Espurt et al. 2011). The lack of structural, geomorphological and thermochronological data from the Eastern Cordillera, with only a few previous studies distributed around our study area (Fig. 1), however, renders the mode and timing of deformation transfer unclear (Gautheron et al. 2013). The mechanisms driving exhumation and surface uplift in the Abancay Deflection also remain enigmatic. The Machu Picchu Batholith, in the core of the Abancay Deflection, has been deeply incised by the Urubamba River and appears as a prime location to investigate the exhumation history of the Abancay Deflection and its drivers (Fig. 1). Here we present new apatite $(\mathrm{U}-\mathrm{Th}) / \mathrm{He}(\mathrm{AHe})$ and apatite fission-track (AFT) dates from the Machu Picchu Batholith. We use age-elevation relationships (AER; e.g. Fitzgerald and Malusà 2019) and inverse time-temperature modelling (QTQt; Gallagher 2012) to unravel the cooling and exhumation history of the core of the Abancay Deflection. As exhumation is generally driven by surface erosion, investigating the geomorphological evolution of an area is crucial to assess potential exhumation drivers. We couple the exhumation history to landscape evolution by extracting normalized steepness $\left(k_{\mathrm{sn}}\right)$ and the $\chi$ indices (Kirby and Whipple 2012; Perron and Royden 2013; Willett et al. 2014; Whipple et al. 2017) for the Urubamba drainage basin. These indices allow identification of slope anomalies (knickpoints) in the river profile and reorganization patterns between drainage basins, respectively. We combine these data to discuss potential mechanisms of Miocene to present exhumation in the Abancay Deflection. 

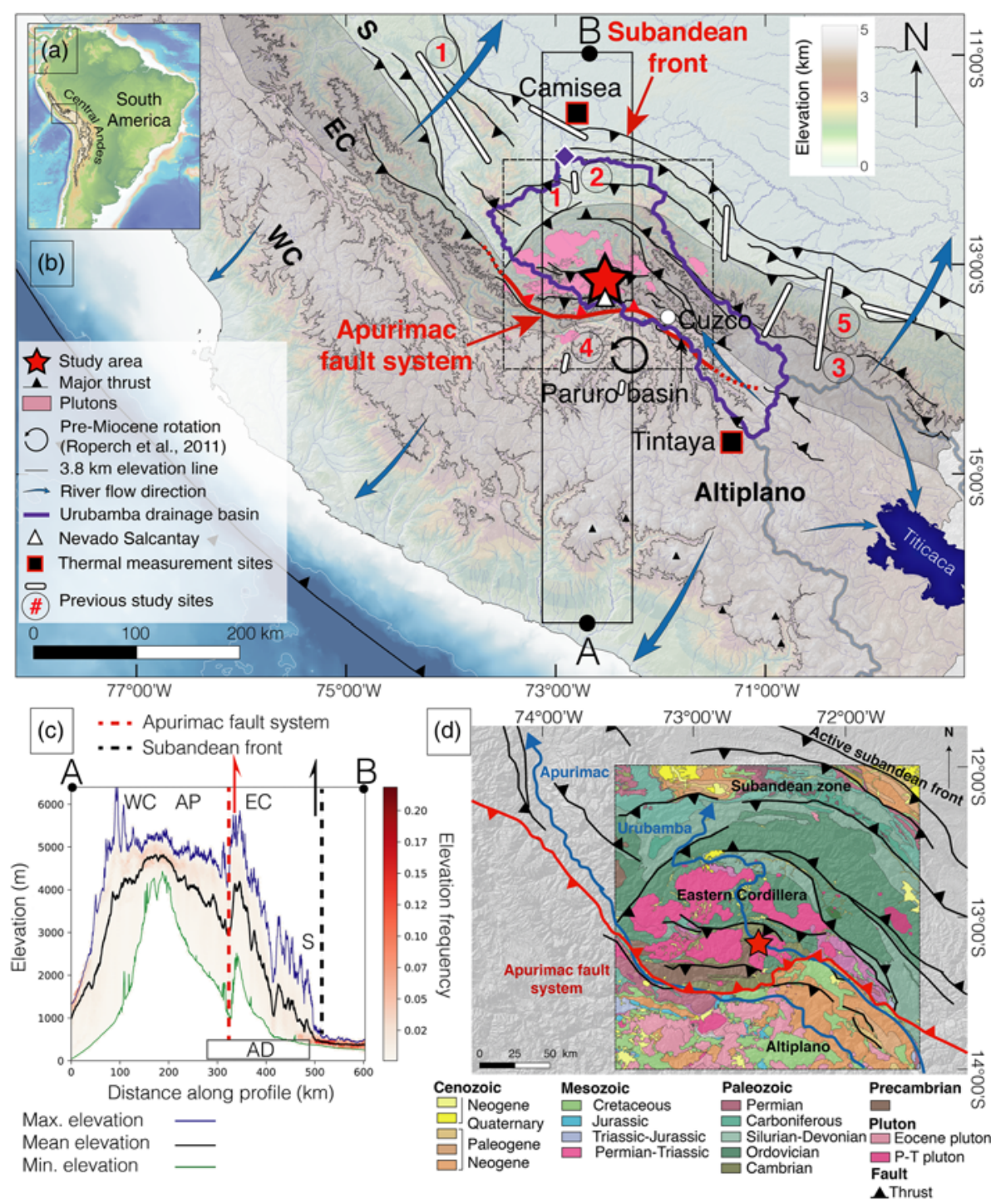

Fig. 1. Topography of the southern Peruvian Andes. (a) Location of the Central Andes within South America. The black line is the $3.8 \mathrm{~km}$ elevation contour outlining the Altiplano. (b) Study area (Abancay Deflection; black dashed square) showing location of sampling profile at Machu Picchu (red star) and major city (white circle). Pink areas correspond to Permo-Triassic intrusive rocks, including the sampled Machu Picchu Batholith. Grey shading indicates the Eastern Cordillera (EC). The rectangle $\mathrm{AB}$ is the location of the topographic swath profile displayed in (c). The Urubamba drainage basin is outlined by the purple contour and its outlet is indicated by the purple diamond. Geology was extracted from 1:100 000 scale INGEMMET maps. Red numbers refer to previous thermochronological studies. 1, Gautheron et al. (2013); 2, Espurt et al. (2011); 3, Lease and Ehlers (2013); 4, Ruiz et al. (2009); 5, Perez et al. (2016). (c) Abancay Deflection topography and relief: $100 \mathrm{~km}$ wide north-south-trending swath profile in southern Peru crossing the Abancay Deflection perpendicular to major east-west faults. A noteworthy feature is the abrupt morphological transition when crossing the Apurimac fault system (red dashed line) between the high and relatively flat Altiplano (AP) and the higher and much more incised Eastern Cordillera (EC) through the Abancay Deflection (AD). (d) Geological map of the Abancay Deflection. Geological map was compiled from 1:100 000

INGEMMET maps available at http:/ geocatmin.ingemmet.gob.pe/geocatmin and personal field observations. Other abbreviations: WC, Western Cordillera; $\mathrm{S}$, Subandes.

\section{Geological setting}

The Abancay Deflection connects the Central and Northern Andes in Peru; its hinge-like character is emphasized by the $>45^{\circ}$ deflection of its fault pattern from the overall NNW-SSE axis of the range (Fig. 1; Marocco 1971). The Abancay Deflection records up to $65^{\circ}$ of Eocene-Early Miocene (c. 40-20 Ma) rotation and marks the tectonic limit between the Bolivian orocline and the straight and narrow Northern Andes (Roperch et al. 2011). In the core of the Abancay Deflection, The Inca citadel of Machu Picchu is built on the Permo-Triassic granitic Machu Picchu Batholith (Eastern Cordillera; Fig. 1), emplaced at $222 \pm 7 \mathrm{Ma}$ (Carlier et al. 1982). The regional crustal-scale Apurimac fault system, c. $15 \mathrm{~km}$ south of the Machu Picchu Batholith, delimits two lithospheric blocks (Carlier et al. 2005) corresponding to two distinct lithotectonic domains: the Eastern Cordillera and the Altiplano (Fig. 1). The Altiplano is characterized by gentle relief and consists of Eocene plutons (50-30 Ma; Mamani et al. 2010) emplaced into Meso-Cenozoic sediments (Carlier et al. 1996; Fig. 1d). This domain was exhumed steadily at moderate rates $\left(c .0 .2 \mathrm{~km} \mathrm{Ma}^{-1}\right)$, at least between 38 and $14 \mathrm{Ma}$ (Ruiz et al. 2009). In contrast, in the higher and deeply incised Eastern Cordillera, numerous PermoTriassic batholiths emplaced into Paleozoic rocks (Mišković et al. 2009; Fig. 1d) crop out. The Eastern Cordillera is characterized by high elevation and relief, and contains the highest peaks east of the
Altiplano (e.g. Salcantay; $6.3 \mathrm{~km}$ a.s.1.; Fig. 1b). On average, the area presents elevation amplitude $>1 \mathrm{~km}$ for a relief wavelength of c. $25 \mathrm{~km}$ (Supplementary Fig. 1). The lack of a Meso-Cenozoic sedimentary cover suggests that the Eastern Cordillera has been a long-lived structural high (Perez et al. 2016). Preliminary AFT ages of c. $2 \mathrm{Ma}$ from two samples from the Machu Picchu Batholith, however, suggest unexpected rapid and recent exhumation (Kennan 2008).

The Urubamba River, flowing at the foot of Machu Picchu, drains both the Altiplano and the Eastern Cordillera towards the Amazon foreland (Figs $1 \mathrm{~b}$ and $2 \mathrm{a}$ ). The present-day climate of the Abancay Deflection is characterized by an abrupt latitudinal precipitation gradient, with rainfall decreasing from $>2.5 \mathrm{~m} \mathrm{a}^{-1}$ in the Subandean domain to $<0.5 \mathrm{~m} \mathrm{a}^{-1}$ in the Altiplano (Supplementary Fig. 2). The topography of the Abancay Deflection constitutes an effective orographic barrier causing this change in precipitation regime (Bookhagen and Strecker 2008; Insel et al. 2010), which has probably been in place since the late Miocene (Poulsen et al. 2010).

\section{Methods}

AHe and AFT systems record the thermal evolution of the upper c. $4 \mathrm{~km}$ of the crust, given their thermal sensitivity ranges spanning c. $40-80^{\circ} \mathrm{C}$ (e.g. Flowers et al. 2009; Gautheron et al. 2009; for a 

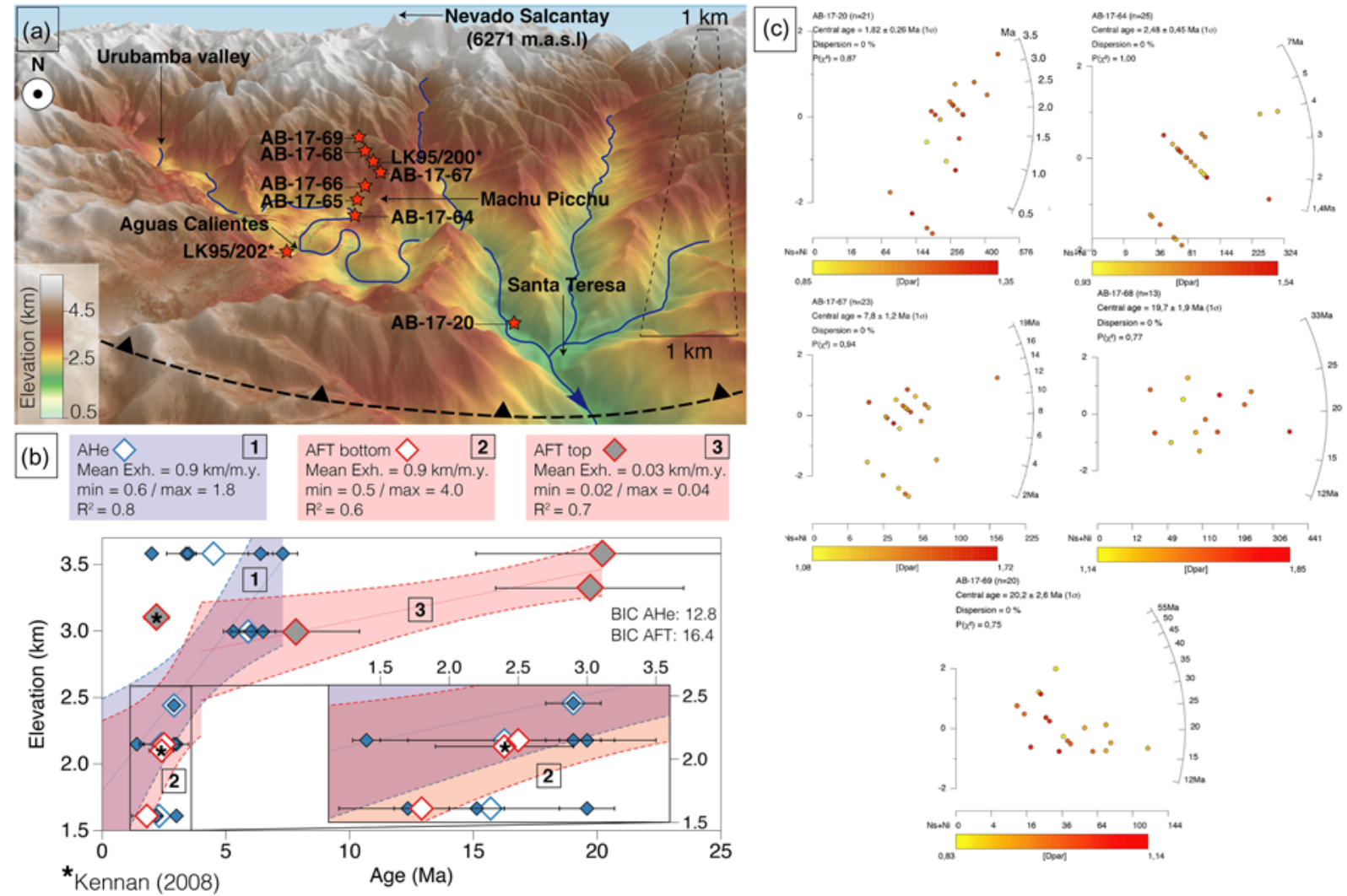

Fig. 2. Thermochronological data. (a) DEM (12 m resolution TanDEM-X data) focusing on the sample locations (red stars). The view is southward with the Urubamba River flowing toward the NW (blue arrow). The blind-thrust plotted is documented as an inherited structure into Paleozoic rocks. (b) Age v. elevation plot for AHe (blue diamonds), AFT bottom (white with red outline diamonds) and AFT top (grey with red outline diamonds). For AHe, filled diamonds represent single-grain ages and open diamonds represent mean AHe ages for each sample. Starred points are from Kennan (2008). Exh., exhumation rates inferred from the age-elevation relationship (AER; coloured dashed lines) with minimum and maximum values indicated by blue and red dotted lines ( $2 \sigma$ confidence intervals) for AHe and AFT respectively. $R^{2}$ (correlation coefficient) for each segment and the Bayesian Information Criterion (BIC) are also indicated (see Glotzbach et al. 2011 for method). (c) AFT single-grain radial plots for each sample.

review see Ault et al. 2019), and c. $75-125^{\circ} \mathrm{C}$ (e.g. Brandon et al. 1998; Reiners and Brandon 2006), allowing the deciphering of exhumation linked to rock uplift and landscape evolution (e.g. Reiners and Shuster 2009; Ault et al. 2019). Here, we combine these data with geomorphological analyses to address landscape evolution and drainage reorganization in response to climatic and/ or tectonic perturbations (e.g. Burbank and Anderson 2012).

\section{Sampling strategy and sample preparation}

Seven samples were collected from the Machu Picchu Batholith along the Inca trail from the town of Santa Teresa to the Phuyupatamarka Inca site, forming a $1.9 \mathrm{~km}$ elevation profile in the vicinity of Machu Picchu (Fig. 2a; Table 1). We sampled the freshest possible in situ outcrops encountered (Supplementary Data). Rock samples were crushed and sieved to extract the 100-

Table 1. Sample locations and lithologies; all samples are from the Triassic granitic Machu Picchu pluton

\begin{tabular}{lccl}
\hline Sample number & Latitude $\left({ }^{\circ} \mathrm{S}\right)$ & Longitude $\left({ }^{\circ} \mathrm{W}\right)$ & Elevation $(\mathrm{m})$ \\
\hline AB-17-20 & 13.14182 & 72.58376 & 1610 \\
AB-17-64 & 13.18747 & 72.52931 & 2149 \\
AB-17-65 & 13.18833 & 72.53428 & 2441 \\
AB-17-66 & 13.19034 & 72.5369 & 2719 \\
AB-17-67 & 13.19288 & 72.54157 & 2996 \\
AB-17-68 & 13.2029 & 72.53497 & 3322 \\
AB-17-69 & 13.20652 & 72.53204 & 3581 \\
\hline
\end{tabular}

$160 \mu \mathrm{m}$ fractions, after which apatite crystals were concentrated using standard magnetic and heavy-liquid techniques.

\section{Apatite $(\mathrm{U}-\mathrm{Th}) / \mathrm{He}(\mathrm{AHe})$ dating}

Euhedral apatite crystals were carefully selected for AHe dating under a binocular microscope to identify minerals without fractures and/or inclusions that would skew the AHe age (Farley 2002). Among the seven samples, five yielded sufficient suitable apatite crystals for AHe dating, from which we extracted 15 single-grain ages. AHe measurements were performed at GEOPS (Université Paris Saclay, France). We determined the individual grain geometry and calculated the alpha-ejection correction factor using the Qt_FT program (Gautheron and Tassan-Got 2010; Ketcham et al. 2011). Individual apatite crystals were encapsulated in platinum tubes and were heated twice for 5 min under ultra-vacuum conditions at high temperature $\left(1050 \pm 50^{\circ} \mathrm{C}\right)$ using an infrared diode laser. The extracted ${ }^{4} \mathrm{He}$ gas was mixed with a known amount of ${ }^{3} \mathrm{He}$; the gas mixture was purified and analysed using a Prisma Quadrupole mass spectrometer. Subsequently, apatite crystals were dissolved in $50 \mu \mathrm{l}$ of $5 \mathrm{~N} \mathrm{HNO}_{3}$ solution containing known amount of ${ }^{235} \mathrm{U},{ }^{230} \mathrm{Th}$, ${ }^{149} \mathrm{Sm}$ and ${ }^{42} \mathrm{Ca}$; an additional $50 \mu \mathrm{l}$ of $5 \mathrm{~N} \mathrm{HNO}_{3}$ was added to the solution. The solution was heated to $70^{\circ} \mathrm{C}$ for $3 \mathrm{~h}$; after cooling, $900 \mu \mathrm{l}$ of distilled water was added. The final solution was analysed using an ELEMENT XR inductively coupled plasma mass spectrometry system; the ${ }^{238} \mathrm{U},{ }^{230} \mathrm{Th}$ and ${ }^{147} \mathrm{Sm}$ concentrations were determined and apatite weight was estimated using the $\mathrm{Ca}$ content, following the method proposed by Evans et al. (2005). Standard Durango apatite crystals were analysed alongside the 
Table 2. QTQt parameters for data inversion

\begin{tabular}{|c|c|c|}
\hline Parameters & Values or flags & References or justifications \\
\hline Explored time interval (Ma) & $0-50$ & Encompassing AHe and AFT data range \\
\hline Explored temperature interval $\left({ }^{\circ} \mathrm{C}\right)$ & $0-140$ & Encompassing AHe and AFT closure temperature \\
\hline Geothermal gradient $\left({ }^{\circ} \mathrm{C} \mathrm{km}^{-1}\right)$ & $25 \pm 15$ & $\begin{array}{l}\text { Broad range; the geothermal gradient measured at the site closest to our sampling is } 16 \pm 2{ }^{\circ} \mathrm{C} \mathrm{km}^{-1} \\
\text { (Henry and Pollack 1988) }\end{array}$ \\
\hline Present-day surface temperature $\left({ }^{\circ} \mathrm{C}\right)$ & $25 \pm 10$ & Gonfiantini et al. (2001) \\
\hline $\begin{array}{l}\text { Allow geothermal gradient to vary } \\
\text { over time }\end{array}$ & Yes & Inversion output consistent with our geothermal gradient assumption \\
\hline Reheating & No & No evidence for reheating event considering the time period explored \\
\hline Number of iterations & 300000 & \\
\hline Etchant & $5.5 \mathrm{M}$ & Sample preparation protocol \\
\hline AFT annealing model & $\begin{array}{l}\text { Ketcham et al. } \\
\qquad(2007)\end{array}$ & Taking into account kinetic variability characterized by $D$ par \\
\hline AHe radiation damage model & $\begin{array}{l}\text { Gautheron et al. } \\
\text { (2009) }\end{array}$ & Taking into account kinetic variability characterized by eU \\
\hline
\end{tabular}

$\mathrm{eU}$, concentration of effective uranium

unknowns to ensure data quality (Supplementary Table 1 ). The $1 \sigma$ error on each single-grain AHe age amounts to $8 \%$, reflecting analytical error and uncertainty on the FT ejection factor correction. More details on the analytical procedure have been given by Recanati et al. (2017).

\section{Apatite fission track (AFT) analysis}

For AFT dating, apatite crystals were manually selected, mounted in epoxy resin and polished at the GTC platform (ISTerre, Grenoble, France). Among the seven samples, five presented sufficient suitable apatite crystals for AFT dating. AFT dating was performed using the external-detector method and $\zeta$-calibration approach (Hurford and Green 1983). Spontaneous fission tracks were revealed by etching at $21{ }^{\circ} \mathrm{C}$ for $20 \mathrm{~s}$ using a $5.5 \mathrm{M} \mathrm{HNO}_{3}$ solution. Induced tracks were implanted in an external mica-sheet detector by thermal-neutron irradiation at the FRM II reactor (Munich, Germany). Tracks were counted and lengths were measured at $1250 \times$ magnification under a Zeiss microscope. Simultaneous measurement of five Durango and five Fish Canyon Tuff age standards allowed a $\zeta$-value of $275 \pm 12$ to be constrained for the operator, Benjamin Gérard. We used the BINOMFIT program (e.g. Ehlers et al. 2005) to calculate AFT central ages (Supplementary Data).

\section{Interpreting age-elevation relationships (AER)}

Age-elevation relationships (AER) provide a first-order estimate of apparent exhumation rates without requiring information on the thermal structure of the crust, with breaks in slope in AER allowing identification of changes in exhumation rate through time (e.g. Wagner et al. 1977; Fitzgerald and Malusà 2019). This approach, however, does not take into account potential inter-sample $\mathrm{AHe} /$ AFT kinetic variability and assumes a quasi-vertical profile (Stüwe et al. 1994). We fitted single- and multi-tier regressions to the AFT and $\mathrm{AHe}$ data from the altitudinal profile data using a Bayesian approach (Glotzbach et al. 2011); the best-fit AER was determined by minimization of the Bayesian Information Criterion (BIC; Schwarz 1978).

\section{Time-temperature modelling}

Time-temperature modelling with QTQt (Gallagher 2012) allows thermal histories to be inferred for individual samples, with the possibility of combining and processing multiple samples from an altitudinal profile. Parameters used for QTQt data inversion are detailed in Table 2. We processed all AHe aliquots displayed in Table 3 and all AFT data presented in Table 4, including tracklength measurements for sample AB-17-69 together. We extracted best-fitting thermal histories for the combined samples from the Machu Picchu profile, exploring the $T-t$ space by calculating the likelihood for 300000 iterations. We implemented the annealing model of Ketcham et al. (2007) and the radiation-damage model of Gautheron et al. (2009) for AFT and AHe respectively. We tested the influence of the AHe diffusion model on the inferred cooling history and found that this is insignificant in our case (Supplementary Fig. 9). We allowed the geothermal gradient to vary over time between commonly inferred values for the Eastern Cordillera (Henry and Pollack 1988; Barnes et al. 2008; Lease and Ehlers 2013); that is, between 10 and $40^{\circ} \mathrm{C} \mathrm{km}^{-1}$. The explored timespan starts at $50 \mathrm{Ma}$, twice the oldest thermochronological age, to take into account the earlier history. We implemented a surfacetemperature lapse rate of $c .6^{\circ} \mathrm{C} \mathrm{km}^{-1}$, as determined for the eastern flank of the inter-tropical Andes (Gonfiantini et al. 2001).

\section{Geomorphological analysis}

For our geomorphological analysis, we used a 1 arc-second (c. $30 \mathrm{~m})$ digital elevation model (DEM) derived from the Shuttle Radar Topography Mission (SRTM V4; Reuter et al. 2007) and $12 \mathrm{~m}$ resolution TanDEM-X data where available (Rizzoli et al. 2017). We extracted the Urubamba drainage basin, its associated drainage network and river longitudinal profiles with Whitebox GAT 3.4 (Lindsay et al. 2015; Fig. 1). We fixed the Urubamba basin outlet location to the Eastern Cordillera-Subandes boundary to avoid potential perturbations in the downstream river profile owing to surface uplift in the Subandean zone (e.g. Gautheron et al. 2013) and in the Amazon foreland (Fitzcarrald arch uplift; Espurt et al. 2007).

The normalized steepness index $\left(k_{\mathrm{sn}}\right)$ quantifies river gradients corrected for upstream drainage area and allows identification of abnormally steep river reaches or knickzones (Kirby and Whipple 2012). The map pattern of $k_{\mathrm{sn}}$ values in a catchment area is a powerful tool to determine active tectonic boundaries and/or edges of a metastable plateau consumed by regressive erosion with knickpoint retreat (Kirby et al. 2003; Wobus et al. 2006). We used Topotoolbox v.2 (Schwanghart and Scherler 2014) to extract $k_{\mathrm{sn}}$ values for the entire hydrographic network of the Urubamba, imposing a mean concavity value $\theta_{\text {ref }}=0.45$ (Wobus et al. 2006).

The variable $\chi$ represents normalized integrated drainage area at any point in the river and has units of length (Perron and Royden 
Table 3. Apatite $(U-T h-S m) / H e$ data

\begin{tabular}{|c|c|c|c|c|c|c|c|c|c|c|c|c|c|c|c|c|}
\hline $\begin{array}{l}\text { Sample } \\
\text { number }\end{array}$ & Morphology & $\begin{array}{l}\text { Length } \\
(\mu \mathrm{m})\end{array}$ & $\begin{array}{l}\text { Width } \\
(\mu \mathrm{m})\end{array}$ & $\begin{array}{l}\text { Thickness } \\
(\mu \mathrm{m})\end{array}$ & $\begin{array}{l}R_{\mathrm{s}} \\
(\mu \mathrm{m})\end{array}$ & $\begin{array}{l}\text { Weight } \\
(\mu \mathrm{g})\end{array}$ & $F_{\mathrm{T}}$ & $\begin{array}{l}{ }^{4} \mathrm{He}(\mathrm{ncc} \\
\left.\mathrm{STP}^{-1}\right)\end{array}$ & $\begin{array}{l}{ }^{238} \mathrm{U} \\
(\mathrm{ppm})\end{array}$ & $\begin{array}{l}{ }^{232} \mathrm{Th} \\
(\mathrm{ppm})\end{array}$ & $\begin{array}{l}{ }^{147} \mathrm{Sm} \\
(\mathrm{ppm})\end{array}$ & $\mathrm{Th} / \mathrm{U}$ & $\begin{array}{l}\mathrm{eU} \\
(\mathrm{ppm})\end{array}$ & $\begin{array}{l}\text { Age } \\
(\mathrm{Ma})\end{array}$ & $\begin{array}{l}\text { Corrected } \\
\text { age }(\mathrm{Ma})\end{array}$ & $\pm 1 \sigma$ \\
\hline AB-17-20A & $2 b$ & 156 & 115 & 107 & 74 & 4.3 & 0.81 & 15283 & 47.4 & 193.0 & 59.0 & 4.1 & 94.0 & 1.4 & 1.7 & 0.1 \\
\hline AB-17-20B & $1 b+1 p y$ & 259 & 101 & 94 & 60 & 4.8 & 0.77 & 17371 & 39.6 & 94.6 & 59.8 & 2.4 & 62.6 & 2.3 & 3.0 & 0.2 \\
\hline AB-17-20C & $2 b$ & 126 & 120 & 99 & 69 & 3.1 & 0.80 & 16046 & 76.4 & 3.3 & 58.1 & 0.0 & 77.5 & 1.7 & 2.2 & 0.2 \\
\hline AB-17-20 & & & & & & & & & & & & & & & $2.3^{*}$ & $0.5^{*}$ \\
\hline AB-17-64D & $1 b+1 p y$ & 209 & 113 & 89 & 57 & 3.7 & 0.75 & 9015 & 21.3 & 53.5 & 80.2 & 2.5 & 35.0 & 2.2 & 2.9 & 0.2 \\
\hline AB-17-64E & $1 b+1 p y$ & 179 & 96 & 90 & 56 & 2.9 & 0.75 & 9430 & 23.7 & 44.4 & 54.1 & 1.9 & 35.0 & 2.3 & 3.0 & 0.2 \\
\hline AB-17-64H & $2 b$ & 102 & 118 & 139 & 70 & 3.6 & 0.80 & 5789 & 28.4 & 54.3 & 62.0 & 1.9 & 41.5 & 1.1 & 1.4 & 0.1 \\
\hline AB-17-64* & & & & & & & & & & & & & & & $2.4^{*}$ & $0.7^{*}$ \\
\hline AB-17-65D & $2 b$ & 205 & 151 & 141 & 97 & 9.6 & 0.85 & 3491 & 7.4 & 17.7 & 46.2 & 2.4 & 11.9 & 2.5 & 2.9 & 0.2 \\
\hline AB-17-65* & & & & & & & & & & & & & & & $2.9^{*}$ & $0.2 *$ \\
\hline AB-17-67C & $2 b$ & 154 & 108 & 84 & 58 & 2.8 & 0.76 & 14056 & 17.5 & 48.1 & 53.8 & 2.7 & 29.3 & 4.0 & 5.3 & 0.4 \\
\hline AB-17-67D & $1 b+1 p y$ & 154 & 96 & 97 & 57 & 2.6 & 0.75 & 16427 & 16.1 & 48.8 & 71.2 & 3.0 & 28.2 & 4.9 & 6.5 & 0.5 \\
\hline AB-17-67F & $2 b$ & 104 & 112 & 72 & 72 & 3.6 & 0.80 & 45191 & 69.1 & 33.5 & 19.3 & 0.5 & 77.2 & 4.8 & 6.0 & 0.4 \\
\hline AB-17-67* & & & & & & & & & & & & & & & $5.9^{*}$ & $0.4^{*}$ \\
\hline AB-17-69B & $1 b+1 p y$ & 202 & 104 & 97 & 61 & 3.8 & 0.77 & 18879 & 35.6 & 92.6 & 32.8 & 2.6 & 58.0 & 2.7 & 3.5 & 0.3 \\
\hline AB-17-69D & $1 b+1 p y$ & 212 & 92 & 66 & 43 & 2.2 & 0.68 & 17806 & 16.6 & 55.8 & 82.4 & 3.4 & 30.4 & 4.9 & 7.3 & 0.6 \\
\hline AB-17-69E & $1 b+1 p y$ & 116 & 75 & 80 & 45 & 1.2 & 0.69 & 9998 & 11.1 & 31.5 & 47.1 & 2.8 & 18.9 & 4.4 & 6.4 & 0.5 \\
\hline AB-17-69I & $2 b$ & 109 & 122 & 126 & 75 & 3.6 & 0.81 & 8191 & 14.2 & 42.2 & 74.1 & 3.0 & 24.4 & 2.7 & 3.4 & 0.2 \\
\hline AB-17-69J & $2 b$ & 125 & 128 & 136 & 85 & 5.0 & 0.83 & 5001 & 13.9 & 45.1 & 78.1 & 3.2 & 24.8 & 1.6 & 2.0 & 0.1 \\
\hline AB-17-69* & & & & & & & & & & & & & & & $4.5^{*}$ & $1.9 *$ \\
\hline
\end{tabular}

Morphology refers to the apatite geometry. $2 \mathrm{~b}$, two broken faces; $1 \mathrm{~b}+1 \mathrm{py}$, one broken face and one hexagonal pyramid. $F_{\mathrm{T}}$, ejection correction factor; $R_{\mathrm{s}}$, sphere equivalent radius of hexagonal crystal (Ketcham et al. 2011; Gautheron et al. 2012).

*AHe arithmetic mean value calculated for plotting (Fig. 2b) with associated error (standard deviation)

2013; Whipple et al. 2017). As it is predicted that drainage divides will migrate in the direction from lower to higher $\chi$ values, the pattern of $\chi$ values across drainage divides can be used to assess their present-day stability or evolution (Willett et al. 2014; Whipple et al. 2017). Combined with independent geomorphological evidence, such patterns can be extrapolated to infer recent drainage migration. We used Topotoolbox v. 2 to calculate $\chi$ for the endorheic Altiplano and the neighbouring Urubamba basin, upstream of the $3.8 \mathrm{~km}$ elevation contour, and focus on the drainage divide equilibrium between these two drainage basins.

\section{Results}

\section{Thermochronology data and modelling}

We report 15 single-grain AHe ages (Table 3) and five AFT ages (Table 4) from five samples. We included two published AFT ages from the same zone (Kennan 2008) in our models (Table 4). Singlegrain AHe and central AFT ages range from 1.4 \pm 0.1 Ma to $7.3 \pm$ $0.6 \mathrm{Ma}( \pm 1 \sigma)$ and from $1.8 \pm 0.6 \mathrm{Ma}$ to $20.2 \pm 5.1 \mathrm{Ma}( \pm 2 \sigma)$, respectively (Tables 3 and 4; Fig. $2 b$ and c). There is a consistent increase in both AHe and AFT ages with elevation (Fig. 2b), with the AFT ages of the two highest samples being much older than all other AFT and AHe ages. AFT ages present a notable dispersion but pass the $\chi^{2}$ test owing to the small number of spontaneous fission tracks in the crystals (Table 4). Only three track lengths were measured because of the young AFT ages and associated low track counts. Only the upper sample provided a mean track length (MTL) of c. $12 \mu \mathrm{m}$ (Table 4; Supplementary Table 2). Etch-pit widths (Dpar), measured as a proxy for apatite composition, range between 0.97 and $1.46 \mu \mathrm{m}$ (Table 4), suggesting that the analysed apatites are fluorapatites, characterized by rapid annealing compared with apatite crystals with higher Dpar values (Donelick et al. 2005).

Bayesian AER modelling reveals that AHe ages are best fit by a single AER with a slope of $0.9_{-0.3}^{+0.9} \mathrm{~km} \mathrm{Ma}^{-1}$ between $c .4$ and c. $2 \mathrm{Ma}$ (Fig. 2b). In contrast, the AFT ages require a two-tier fit, with the higher elevation samples showing an AER with a slope of $0.03 \pm 0.01 \mathrm{~km} \mathrm{Ma}^{-1}$ (c. 20 to c. $4 \mathrm{Ma}$; Fig. 2b) and the lower elevation samples an AER with a slope of $0.9_{-0.4}^{+3.1} \mathrm{~km} \mathrm{Ma}^{-1}$ (c. 4 to c. $2 \mathrm{Ma}$; Fig. 2b); the latter is compatible with the AHe results.

Time-temperature inversions with QTQt reveal slow continuous cooling from c. 20 to $4.0 \pm 0.6 \mathrm{Ma}$ at a rate of $0.7 \pm 0.2{ }^{\circ} \mathrm{C} \mathrm{Ma}^{-1}$,

Table 4. Apatite fission-track data

\begin{tabular}{|c|c|c|c|c|c|c|c|c|c|c|c|c|c|c|c|c|}
\hline $\begin{array}{l}\text { Sample } \\
\text { number }\end{array}$ & $n$ & $\begin{array}{l}\rho_{\mathrm{s}}\left(10^{5}\right. \\
\left.\mathrm{cm}^{-2}\right)\end{array}$ & $N_{\mathrm{s}}$ & $\begin{array}{l}\rho_{\mathrm{i}}\left(10^{5}\right. \\
\left.\mathrm{cm}^{-2}\right)\end{array}$ & $N_{\mathrm{i}}$ & $\begin{array}{l}\rho_{\mathrm{d}}\left(10^{5}\right. \\
\left.\mathrm{cm}^{-2}\right)\end{array}$ & $\begin{array}{l}P \\
\left(\chi^{2}\right)\end{array}$ & $\begin{array}{l}\text { Dispersion } \\
(\%)\end{array}$ & $\begin{array}{l}\text { Central age } \\
(\mathrm{Ma})\end{array}$ & $\pm 2 \sigma$ & $\begin{array}{l}\mathrm{U} \\
(\mathrm{ppm})\end{array}$ & $\pm 1 \sigma$ & $\begin{array}{l}N \\
D_{\text {par }}\end{array}$ & $\begin{array}{l}\mathrm{M} D_{\text {par }} \\
(\mu \mathrm{m})\end{array}$ & $\begin{array}{l}n \\
\mathrm{TL}\end{array}$ & $\begin{array}{l}\text { MTL } \\
(\mu \mathrm{m})\end{array}$ \\
\hline AB-17-20 & 21 & 0.49 & (51) & 50.3 & (5297) & 13.8 & 87.5 & 0.4 & 1.8 & 0.6 & 55 & 2 & 67 & 1.16 & n.d. & n.d. \\
\hline AB-17-64 & 25 & 0.25 & (31) & 19.6 & (2451) & 14.2 & 99.8 & 0.2 & 2.5 & 1.0 & 21 & 1 & 76 & 1.21 & n.d. & n.d. \\
\hline AB-17-67 & 23 & 0.57 & (41) & 14.3 & (1029) & 14.3 & 93.5 & 0.6 & 7.8 & 2.6 & 15 & 1 & 89 & 1.35 & n.d. & n.d. \\
\hline AB-17-68 & 13 & 5.46 & (154) & 54.7 & (1541) & 14.3 & 76.8 & 0.2 & 19.7 & 3.8 & 57 & 3 & 74 & 1.46 & n.d. & n.d. \\
\hline AB-17-69 & 20 & 1.32 & (78) & 12.9 & $(763)$ & 14.4 & 74.9 & 0.3 & 20.2 & 5.1 & 14 & 1 & 42 & 0.97 & 3 & 11.92 \\
\hline LK95/200* & 30 & n.r. & n.r. & n.r. & n.r. & n.r. & 46.5 & n.r. & 2.2 & 0.5 & n.r. & n.r. & n.r. & n.r. & n.r. & n.r. \\
\hline LK95/202* & 30 & n.r. & n.r. & n.r. & n.r. & n.r. & 97.0 & n.r. & 2.4 & 0.5 & n.r. & n.r. & n.r. & n.r. & n.r. & n.r. \\
\hline
\end{tabular}

Fission-track age is reported as central age (Galbraith and Laslett 1993). Samples were counted dry with a BX51 Olympus microscope at $1250 \times$ magnification. Ages were calculated with the BINOMFIT program (Ehlers et al. 2005), using a zeta value of $275.18 \pm 11.53$ and the IRMM 540 uranium glass standard (15 ppm U). $n$, number of analysed grains; $\rho_{\mathrm{s}}$, spontaneous track density; $N_{\mathrm{s}}$, number of spontaneous tracks; $\rho_{\mathrm{i}}$, induced track density; $N_{\mathrm{i}}$, number of induced tracks; $\rho_{\mathrm{d}}$, dosimeter tracks density; $P\left(\chi^{2}\right)$, probability of obtaining the $\chi^{2}$ value for $n$ degree of freedom $\left(n=\right.$ number of crystals - 1); $n D_{\text {par }}$, number of $D_{\text {par }}$ measured; M $D_{\text {par }}$, mean $D_{\text {par }}$ value (i.e. average etch pit diameter of fission track); $n$ TL, number of track lengths measured; MTL, mean track lengths of horizontally confined tracks; n.d., no data; n.r., not reported.

*Previously published data (Kennan 2008). For samples LK95/200 and LK95/202, elevations are respectively $3.1 \mathrm{~km}$ and $2.1 \mathrm{~km}$. 


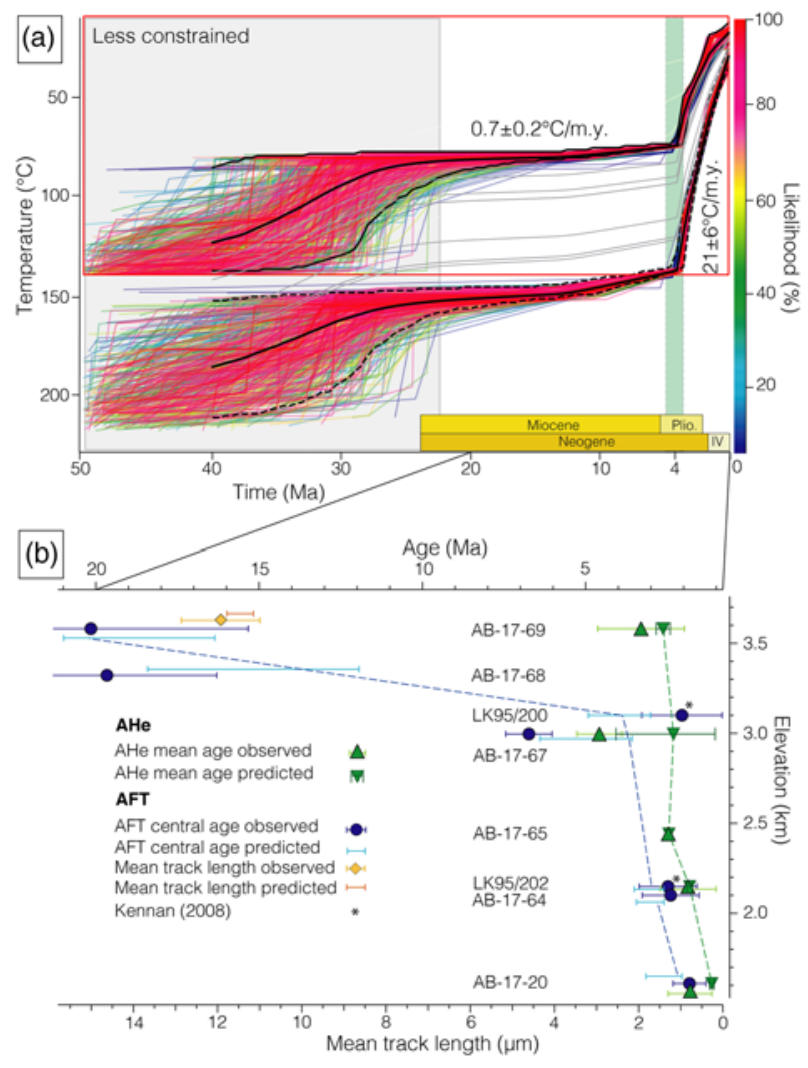

Fig. 3. Time-temperature ( $T-t)$ modelling. (a) Time-temperature paths obtained by inversion of AHe and AFT thermochronology data using QTQt. The red rectangle shows the explored $T-t$ range for inversion. Coloured lines show the $T-t$ paths for the top and the bottom samples with their respective likelihood (colour scale on right). Continuous and dashed black lines show the expected model and its 95\% reliable interval for the thermal histories of the top and bottom samples, respectively. Grey lines represent the expected cooling paths for intermediate samples. The green vertical band indicates acceleration of cooling at $4.0 \pm 0.6 \mathrm{Ma}$. Cooling rates derived from QTQt are indicated on the graph. (b) Fit of best-fit QTQt model predictions to the data for the Machu Picchu elevation profile. increasing to $21 \pm 6^{\circ} \mathrm{C} \mathrm{Ma}^{-1}$ since c. $4 \mathrm{Ma}$ (Fig. 3). AHe and AFT ages predicted by the best-fit model fit the observed ages within error.

\section{Geomorphological analysis}

The highest $k_{\mathrm{sn}}$ values $\left(>1000 \mathrm{~m}^{0.9}\right)$ in the Urubamba drainage basin are focused along a SW-NE band orthogonal to the drainage direction (Fig. $4 \mathrm{~b}$ ). This zone of high $k_{\mathrm{sn}}$ corresponds to kilometrescale knickzones in the Urubamba main stem and its tributaries, where the rivers actively incise bedrock (Fig. 5c). In contrast, alluvial portions upstream (Fig. 5d) correspond to the lowest $k_{\mathrm{sn}}$ values $\left(<10 \mathrm{~m}^{0.9}\right.$; Fig. $\left.4 \mathrm{~b}\right)$. Along the drainage divide between the endorheic Altiplano and externally drained Urubamba drainage basins, $\chi$ values (calculated from a base level at $3.8 \mathrm{~km}$ ) are noticeably higher in the Altiplano $\left(c .10^{5} \mathrm{~m}\right)$ than in the Urubamba basin (c. $10^{3}$ m; Fig. 4c).

\section{Discussion}

\section{Miocene-Present exhumation of the Machu Picchu Batholith}

The data for both thermochronometric systems suggest rapid cooling starting at c. $4 \mathrm{Ma}$. It is reasonable to assume that the Machu Picchu Batholith did not experience reheating since the Miocene, considering the lack of evidence for volcanic activity and/ or sedimentary burial (Perez et al. 2016). Magmatic activity in the Abancay Deflection ceased after c. $30 \mathrm{Ma}$ (Mamani et al. 2010); any potential associated thermal perturbation would not have affected the Miocene thermal history. Nonetheless, to explore potential temporal variability of the geothermal gradient, we allow it to vary over time in the range $25 \pm 15^{\circ} \mathrm{C} \mathrm{km}^{-1}$ during timetemperature inversions. The model does not converge to a single range of palaeo-geothermal gradient estimates. As it is not possible to estimate the geothermal gradient accurately in the past, we consider it constant in time and space in the following calculations, following previous work (e.g. Barnes et al. 2012; Perez et al. 2016).

The value of the geothermal gradient is a crucial choice when translating cooling rates (inferred from time-temperature modelling) into exhumation rates. As the Abancay Deflection is devoid of direct measurements of its thermal structure, we explore two options
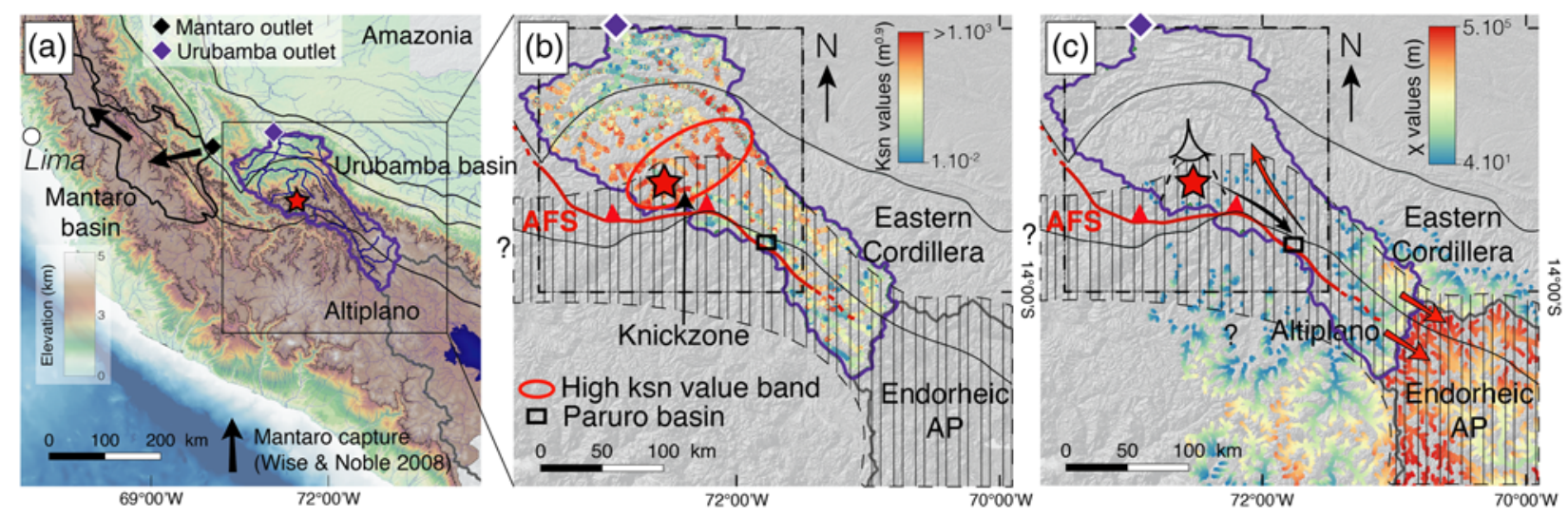

Fig. 4. Quantitative geomorphology of the Urubamba River drainage basin. (a) Urubamba (purple) and Mantaro (black) watershed locations in southern Peru. Blue lines are rivers. (b) $k_{\mathrm{sn}}$ map for the Urubamba drainage basin. Higher $k_{\mathrm{sn}}$ values (in warm colours) are aligned in a band orthogonal to the main elongation axis of the Urubamba drainage basin, suggesting capture of a palaeo-Altiplano (Wobus et al. 2003, 2006). (c) $\chi$ map for the Urubamba drainage basin. $\chi$ values were calculated with an elevation threshold of $3.8 \mathrm{~km}$ corresponding to the endorheic Lake Titicaca base level. The $\chi$ gradient across the drainage divide between the Urubamba and the endorheic Altiplano suggests that it is actively migrating southward (red arrows), implying continuing capture of the plateau. The black and the red curved arrows represent respectively the drainage direction for 9-7 Ma (Sundell et al. 2018) and for the present day. The 'eye' icon represents the view direction of the 3D DEM in Fig. 2a. In (a-c), the red star is the sample location close to Machu Picchu and the dashed black square is the Abancay Deflection. The grey polygon outlines the present-day endorheic Altiplano and the black-hatched polygon represents the ante-4 Ma northern extension of the palaeo-endorheic Altiplano. AFS, Apurimac fault system. 


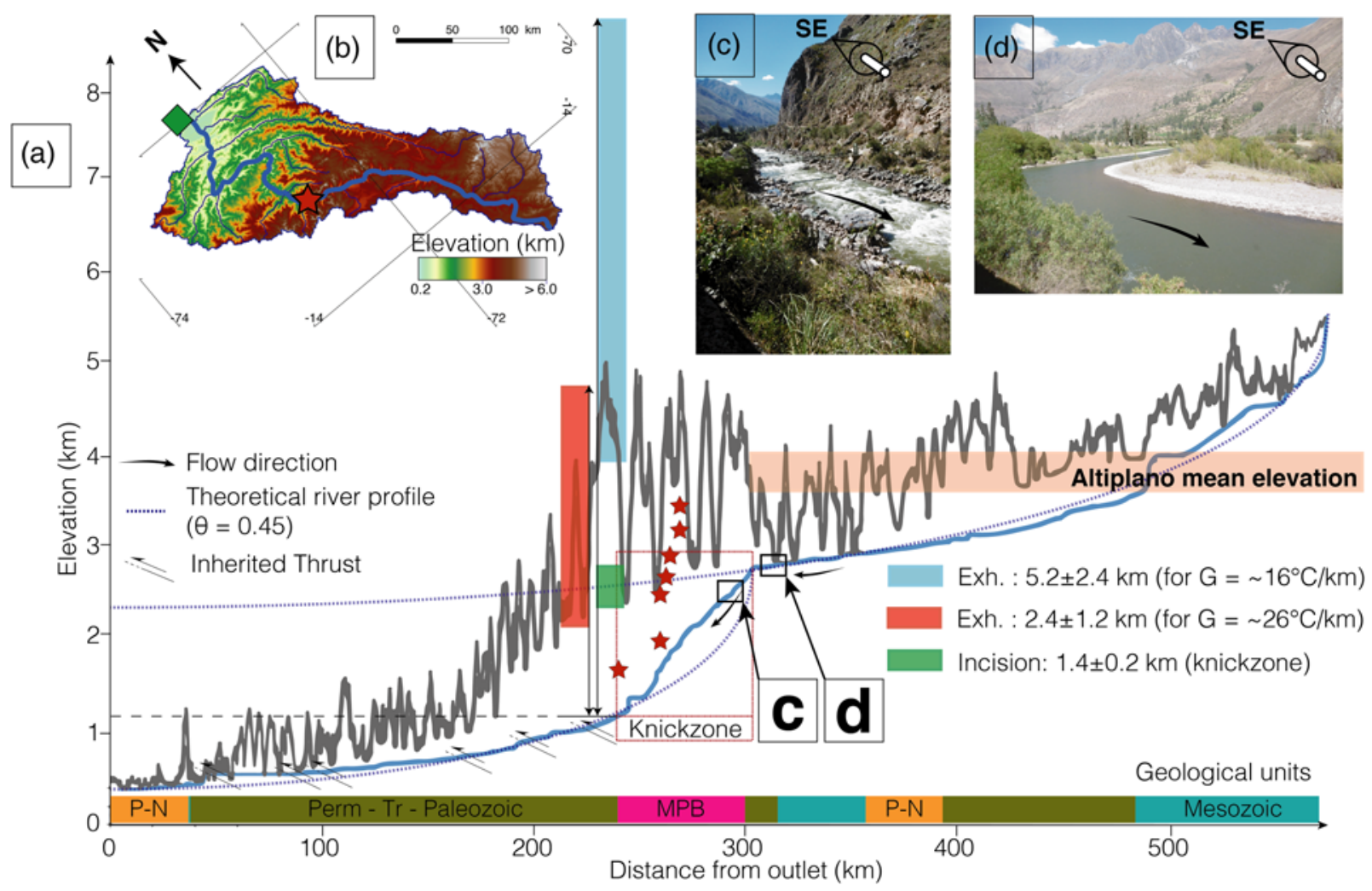

Fig. 5. (a) Urubamba river profile (blue) crossing the Machu Picchu Batholith. Red stars show projected location of the samples collected in this study. The orange horizontal band represents the mean elevation of the Altiplano (calculated from a swath profile) and the dark grey line is the mean topography in a $5 \mathrm{~km}$ swath following the Urubamba River. The blue and red vertical bands show the estimated total exhumation since 4 Ma for an assumed 'cold' and 'warm' geotherm, respectively, at the same location at the base of the knickzone. The green vertical band shows the minimum incision of the Urubamba River computed by the difference between the theoretical river profile reconstructed from the river profile above the knickzone and the present-day river profile at the foot of the knickzone. Vertical exhumation or incision rectangles are slightly shifted to avoid overprinting the signals displayed. Total exhumation is calculated taking into account minimum and maximum values for exhumation rates and timing of acceleration. The error on the incision estimate for the knickzone is propagated from a 15\% uncertainty in the concavity value $(\theta)$ derived from river-profile fitting (Kirby and Whipple 2012). (b) DEM of the Urubamba drainage basin with its outlet (green diamond). The main Urubamba river (thick blue curve) is plotted in (a). The red star indicates the location of the knickzone and sampling profile. Inset photographs (c) and (d) show the morphological change of the Urubamba River from meandering upstream (d) to rapids in a canyon (knickzone; c). MPB, Machu Picchu Batholith; P-N, Paleo-Neogene.

to estimate the geothermal gradient in our study area. The first consists in using the nearest available measurements. Henry and Pollack (1988) reported a measured modern-day geothermal gradient of $c .14^{\circ} \mathrm{C} \mathrm{km}^{-1}$ from the Tintaya mine on the Altiplano (Fig. 1), whereas Espurt et al. (2011) inferred a Miocene geothermal gradient of $c .17^{\circ} \mathrm{C} \mathrm{km}^{-1}$ in the Camisea area in the Subandean domain (Fig. 1), leading to an estimated geothermal gradient of 16 $\pm 2{ }^{\circ} \mathrm{C} \mathrm{km}^{-1}$. The second option is to take into account more distant data available for the Eastern Cordillera of Bolivia, which suggest a somewhat higher geothermal gradient of $26 \pm 8^{\circ} \mathrm{C} \mathrm{km}^{-1}$ (Barnes et al. 2008). We will refer to these two estimates of the geothermal gradient as 'cold' (based on local data) and 'warm' (based on Barnes et al. 2008). Considering stable, linear and spatially uniform geothermal gradients of $16 \pm 2^{\circ} \mathrm{C} \mathrm{km}^{-1}$ or $26 \pm 8^{\circ} \mathrm{C} \mathrm{km}^{-1}$ ('cold' v. 'warm'), we can translate the cooling rates from the timetemperature inversions to exhumation rates. Between $c .20$ and $c$. $4 \mathrm{Ma}$, exhumation rates were $0.05 \pm 0.02 \mathrm{~km} \mathrm{Ma}^{-1}$ ('cold' gradient) or $0.03 \pm 0.01 \mathrm{~km} \mathrm{Ma}^{-1}$ ('warm' gradient); that is, very similar independent of the chosen geothermal gradient. For the period from c. 4 Ma to present day, however, the choice of geothermal gradient leads to significant differences in predicted exhumation rates. If the 'cold' gradient is used the exhumation rate is $1.3 \pm 0.6 \mathrm{~km} \mathrm{Ma}^{-1}$, whereas for the 'warm' gradient the exhumation rate decreases to $0.9 \pm 0.3 \mathrm{~km} \mathrm{Ma}^{-1}$. Both values are consistent within errors with those inferred from the AER analysis $\left(0.9_{-0.3}^{+0.9} \mathrm{~km} \mathrm{Ma}^{-1}\right.$ for the AHe data; Fig. 2b). In the following discussion, we will interpret exhumation rates values computed from QTQt cooling dynamic.

The local relief may also influence estimated exhumation rates, as topography deflects isotherms with an exponentially decreasing influence downward (Braun 2002; Braun et al. 2006). Therefore, the closure depth of thermochronometric systems is relief dependent, in particular for the lowest-temperature system (i.e. AHe). Using a relief wavelength $\lambda=25 \pm 8 \mathrm{~km}$ and relief amplitude $>1 \mathrm{~km}$ (Supplementary Fig. 1) and the calculation method of Mancktelow and Grasemann (1997) (see also Braun et al. 2006), leads to deflections of the $100^{\circ} \mathrm{C}$ isotherm of $280-570 \mathrm{~m}$ depending on the chosen exhumation rate but does not significantly affect the exhumation-rate estimates.

Thus our thermochronology data from the Machu Picchu Batholith clearly show an c. 30 -fold increase in exhumation rate in the Pliocene, from $<0.05$ to $>0.9 \mathrm{~km} \mathrm{Ma}^{-1}$. Although the exact rate and amount of exhumation since this time depend on assumed values for the geothermal gradient and the influence of relief, the relative increase as well as its timing at $4.0 \pm 0.6 \mathrm{Ma}$ is robust.

\section{Geomorphological evidence for capture of Altiplano drainage}

The modern Abancay Deflection is externally drained and has anomalously high topography, high relief and outcropping 
basement batholiths, in contrast to the neighbouring low-relief Altiplano (Fig. 1c). The Machu Picchu area is set within a SW-NEtrending band of high $k_{\mathrm{sn}}$ values (Fig. $4 \mathrm{~b}$ ), with much lower $k_{\mathrm{sn}}$ values found upstream in the Altiplano region. The Urubamba River, draining the Abancay Deflection, is one of the most distant tributaries of the Amazon. From its source in the Altiplano, it flows parallel to the Andean range at $3.8 \mathrm{~km}$ elevation for c. $150 \mathrm{~km}$ before it cuts the Machu Picchu Batholith in a $>1 \mathrm{~km}$ deep canyon, associated with a major knickzone (Fig. 5). This knickzone appears to be confined to the Machu Picchu Batholith (Fig. 5a), which presumably has greater rock-strength than surrounding units. Although the SW-NE band of high $k_{\mathrm{sn}}$ values is mostly contained within intrusive rocks and metamorphic sediments (Fig. 1), these rocks also occur widely outside this band. Therefore, the band of high $k_{\mathrm{sn}}$ values does not appear to be purely lithologically controlled and presumably reflects a geomorphological or structural transition. In the absence of a major tectonic structure associated with it, we interpret the major knickzone associated with this band by baselevel fall in the Urubamba river system owing to capture of a former endorheic catchment (which would have been a northward extension of the Altiplano; Fig. 4). Although we cannot determine the exact location of the river capture, it must have happened downstream of the present-day location of the knickzone. Capture is a continuing process, as shown by the pattern of $\chi$ values that points to drainage-divide migration toward the SE; that is, expansion of the Urubamba catchment to the detriment of the endorheic Altiplano (Fig. 4c). Although lithology does not appear to be a primary control on the pattern of $k_{\mathrm{sn}}$ values, headward propagation of incision from the foreland into the highlands may be stalling within the hard rocks of the Machu Picchu Batholith, limiting incision further upstream, as suggested by the alluvial river channels found upstream of the knickzone (Fig. 5c).

\section{Miocene surface uplift of the northern Altiplano without exhumation}

Our data imply slow exhumation between 20 and $4 \mathrm{Ma}(c .0 .6 \mathrm{~km}$ in c. $16 \mathrm{myr}$ ), consistent with the record from the Altiplano to the south that suggests steady and moderate exhumation between 38 and 14 Ma (Ruiz et al. 2009; Supplementary Fig. 10). In contrast, the Eastern Cordillera record to the SE suggests significant Miocene exhumation (Lease and Ehlers 2013; Perez et al. 2016). Several palaeo-elevation estimates (e.g. Sundell et al. 2019) indicate that the elevation of both the Eastern Cordillera and the neighbouring Altiplano grew by c. 2 to $c .4 \mathrm{~km}$ between 20 and $5 \mathrm{Ma}$; the Abancay Deflection must have reached its present-day elevation before $5 \mathrm{Ma}$. Thus, slow exhumation of the core of the Abancay Deflection during the Miocene appears to be coeval with surface uplift of the northern Altiplano. Although a pulse of exhumation would be expected to accompany surface uplift, both the Abancay Deflection (this study) and the northern Altiplano (Ruiz et al. 2009) record steady and moderate exhumation rates. There are two potential explanations for diminished Miocene denudation within this rising orogen: (1) establishment of aridity owing to the development of an orographic barrier (Strecker et al. 2007), and/or (2) a high-elevation endorheic local base level. Provenance studies in the Paruro basin south of Cuzco, based on detrital zircon U-Pb dating (Sundell et al. 2018), suggest that the Machu Picchu area (specifically the Ollantaytambo Formation into which the Machu Picchu Batholith intruded; Bahlburg et al. 2006) was one of the numerous sources for late-Miocene (c. 9 to $c .7 \mathrm{Ma}$ ) Altiplano basin sediments. In contrast, rocks from the Machu Picchu area are currently exported toward the Amazon foreland via the modern Urubamba drainage network (Fig. 4c). This contrast implies a major drainage reversal since the late Miocene. The combined data strongly suggest that the Abancay Deflection (including the Machu Picchu Batholith) was part of a slowly eroding endorheic environment during the Miocene, undergoing rock and surface uplift but little exhumation, as it was associated with a high-elevation local base level comparable with the present-day endorheic Altiplano.

\section{Drivers of Pliocene exhumation}

Our data suggest that exhumation rates increased dramatically at $4 \mathrm{Ma}$ (Figs $2 \mathrm{~b}$ and $3 \mathrm{a}$ ). The total amount of exhumation since that time, however, depends on the assumed geothermal gradient. If the 'cold' Altiplano option is considered, total exhumation since $c$. $4 \mathrm{Ma}$ amounts to $5.2 \pm 2.4 \mathrm{~km}$; in contrast, if the 'warm' Eastern Cordillera option is used, this number decreases to $2.4 \pm 1.2 \mathrm{~km}$. Regardless of the choice of geothermal gradient, these values are higher than those obtained in the Eastern Cordillera further south in Bolivia for the same period (c. $0.6 \mathrm{~km} \mathrm{Ma}^{-1}$; Lease and Ehlers 2013; Fig. 1, reference 3).

Fitting equilibrium profiles to the reaches of the Urubamba River above and below the knickzone (Kirby and Whipple 2012) allows us to derive a minimum depth of incision of $1.4 \pm 0.2 \mathrm{~km}$ at the base of the knickzone (Fig. 5). This amount represents the height of the rock column above the present-day knickzone before incision. We suggest that the Urubamba River captured a former c. $3.8 \mathrm{~km}$ high endorheic drainage system of the Altiplano, initiating canyon carving at c. $4 \mathrm{Ma}$ (Fig. 4). A similar scenario of endorheic basin capture and opening to the Amazon is recorded in the adjacent Mantaro River catchment to the north (Fig. 4a; Wise and Noble 2008).

Either climatic or tectonic changes could have further amplified incision. Two major but diachronous climatic events affected the Central Andes since the Miocene, both linked to emplacement and/ or intensification of the South American monsoon leading to climate-driven incision of the Eastern Cordillera. The first is global Pliocene cooling between 4 and $2 \mathrm{Ma}$ (Zhang et al. 2001), which has been interpreted as the remote driver for incision of canyons cutting perpendicularly through the Eastern Cordillera in southern Peru and Bolivia (Lease and Ehlers 2013). This cooling signal is even documented in northern Peru in the Cordillera Blanca area (Margirier et al. 2015). An older and more regional climatic event involves increased precipitation and possibly related intensified erosion in the Eastern Cordillera owing to surface uplift in the Central Andes during the Late Miocene (c. 10 to $6 \mathrm{Ma}$; Uba et al. 2007; Poulsen et al. 2010). This precipitation gradient pattern is still valid at present (Supplementary Fig. 2).

Whether incision was climatically amplified or not, a first-order observation from our data is that the reconstructed amount of incision $(1.4 \pm 0.2 \mathrm{~km})$ overlaps the lower end of our exhumation estimate for a 'warm' geothermal gradient $(2.4 \pm 1.2 \mathrm{~km}$; Fig. 5) but if a 'cold' geothermal gradient is assumed, the amount of canyon incision is significantly smaller than total exhumation at river level since $4 \mathrm{Ma}(5.2 \pm 2.4 \mathrm{~km}$; Fig. 5). Some additional uplift will be caused by the isostatic response to mass removal by river incision. Zeilinger and Schlunegger (2007) quantified the maximum deflection owing to isostatic rebound to river incision for the Rio La Paz in the Bolivian Eastern Cordillera, a system similar in scale to the Urubamba River, and found that for an elastic thickness of $17.5 \pm 2.5 \mathrm{~km}$ (Pérez-Gussinyé et al. 2008) this would be $c .0 .2 \mathrm{~km}$; that is, a negligible amount. Furthermore, glaciations could also promote erosion and incision. Postglacial isostatic rebound could potentially accelerate the surface uplift and exhumation. These observations are particularly true for fully glaciated area such as the Cordillera Blanca in northern Peru (Margirier et al. 2016). In contrast, present-day glaciers represent an insignificant part of our study area, as they occupy only $>4.5 \mathrm{~km}$ elevation zones (Licciardi et al. 2009). In this intertropical context, they did not reach $<4 \mathrm{~km}$ elevation in the past, with drier climatic conditions limiting their 
spatial extent (Pleistocene; Fox and Bloom 1994). We thus do not take into account potential glacial influence on exhumation for the Machu Picchu region. A substantial amount of exhumation since $4 \mathrm{Ma}(1.0 \pm 1.4 \mathrm{~km}$ for the 'warm' geotherm case; $3.8 \pm 2.6 \mathrm{~km}$ for the 'cold' geotherm case) thus has to be tectonic in origin. Knowledge of the (active?) tectonics of the Abancay Deflection remains limited because of its complex structural setting, dense vegetation and difficult access. Initiation of compression in the Subandean fold-and-thrust belt to the NE of the Abancay Deflection at c. $14 \mathrm{Ma}$ is associated with thick-skinned tectonics (Espurt et al. 2011) that potentially could affect the basement of the Abancay Deflection. The diachronous $c$. 4 Ma acceleration of exhumation recorded in the Machu Picchu Batholith, in either of the hypotheses, suggests that the Abancay Deflection is tectonically decoupled from its surroundings. We propose activity of the Apurimac fault system to explain the additional post-Miocene exhumation (not explained by incision). Inherited normal faults reactivated as thrusts affecting the Eastern Cordillera are already documented further south in Bolivia (Perez et al. 2016), which could be comparable with the Apurimac fault system context. The structure of the Abancay Deflection developed by horizontal strike-slip faults with limited vertical motion during the Miocene (c. 20 to $4 \mathrm{Ma}$; Dalmayrac et al. 1980; Roperch et al. 2011; this study). A change to a more compressional setting at $4 \mathrm{Ma}$ may have led to significant exhumation of the Abancay Deflection along the Apurimac fault system.

\section{Conclusion}

The opportunity to sample in the Machu Picchu Geopark provides a unique insight into a key area of the segmented Andean orogen: the Abancay Deflection. Our new thermochronology data and modelling from the Machu Picchu Batholith in the core of the Abancay Deflection reveal slow exhumation during the Miocene, despite evidence for both contemporaneous surface uplift and tectonic shortening of the northern Altiplano. This temporal decoupling of uplift and exhumation supports the hypothesis of an endorheic northern Altiplano prior to the Pliocene, as previously suggested from provenance data. Sediments seemed to be transported from the Eastern Cordillera toward the Altiplano in the late Miocene (Sundell et al. 2018) whereas the modern drainage direction is reversed toward the Amazon foreland. Geomorphological analysis of the Urubamba drainage basin suggests that it evolved through capture of an endorheic drainage system. At c. $4 \mathrm{Ma}$, drainage capture occurred close to our sampling location, resulting in base-level fall and causing a knickzone associated with significant incision to form at the point of capture. As a result of this increased focused incision, exhumation in this area increased since $4 \mathrm{Ma}$. The knickpoint has retreated toward the SE with the granite exposed all along the highrelief knickzone. The process driving exhumation is, however, probably more complex. As the total amount of exhumation may be larger than the maximum allowable amount of incision, depending on assumptions on the value of the geothermal gradient, additional tectonic uplift may be controlled by the Apurimac fault system.

Acknowledgments We thank SERNANP, INGEMMET (Cuzco-PATA convenio 006-2016-Fondecyt) and F. Astete (National Archaeological Park of Machu Picchu), for permission to work along the Inca trail and for provided facilities. We thank P. H. Leloup and G. Mahéo (Géode laboratory, Lyon) and the GTC platform (F. Coeur and F. Sénebier, ISTerre, Grenoble) for sample processing, as well as M. Balvay, R. Pinna-Jamme and F. Haurine for assistance during AFT and AHe dating. We also thank S. Hall, S. Noriega Londoño and an anonymous reviewer for instructive feedback on this paper.

Author contributions BG: conceptualization (equal), investigation (lead), supervision (equal), visualization (lead), writing - original draft (lead), writing - review \& editing (equal); LA: conceptualization (equal), funding acquisition (lead), writing - review \& editing (equal); XR: conceptualization (equal), funding acquisition (lead), supervision (equal), visualization (equal), writing - review \& editing (equal); CG: investigation (equal), writing - review \& editing (equal); PvdB: investigation (equal), visualization (equal), writing review \& editing (equal); MB: investigation (equal), writing - review \& editing (equal); CB: resources (supporting), writing - review \& editing (supporting); FD: resources (supporting), writing - review \& editing (supporting)

Funding This work was funded by the Agence Nationale de la Recherche (12-NS06-0005-01 for AHe analyses), Cuzco-PATA (006-2016-Fondecyt), Institut de Recherche pour le Développement, l'Institut des Sciences de la Terre and INSU.

Data availability All data generated or analysed during this study are included in this published article (and its supplementary information files).

\section{Scientific editing by Yuntao Tian}

\section{References}

Ault, A.K., Gautheron, C. and King, G.E. 2019. Innovations in (U-Th)/He, fission-track, and trapped-charge thermochronometry with applications to earthquakes, weathering, surface-mantle connections, and the growth and decay of mountains. Tectonics, 38, 3705-3739, https://doi.org/10.1029/ $2018 \mathrm{tc} 005312$

Bahlburg, H., Carlotto, V. and Cárdenas, J. 2006. Evidence of Early to Middle Ordovician arc volcanism in the Cordillera Oriental and Altiplano of southern Peru, Ollantaytambo Formation and Umachiri beds. Journal of South American Earth Sciences, 22, 52-65, https://doi.org/10.1016/j.jsames.2006. 09.001

Barnes, J.B. and Ehlers, T.A. 2009. End member models for Andean Plateau uplift. Earth-Science Reviews, 97, 105-132, https://doi.org/10.1016/j. earscirev.2009.08.003

Barnes, J.B., Ehlers, T.A., McQuarrie, N., O'Sullivan, P.B. and Tawackoli, S. 2008. Thermochronometer record of central Andean Plateau growth, Bolivia (19.5 ${ }^{\circ}$ S). Tectonics, 27, https://doi.org/10.1029/2007TC002174

Barnes, J.B., Ehlers, T.A., Insel, N., McQuarrie, N. and Poulsen, C.J. 2012. Linking orography, climate, and exhumation across the central Andes. Geology, 40, 1135-1138, https://doi.org/10.1130/G33229.1

Bookhagen, B. and Strecker, M.R. 2008. Orographic barriers, high-resolution TRMM rainfall, and relief variations along the eastern Andes. Geophysical Research Letters, 35, 1-6, https://doi.org/10.1029/2007GL032011

Brandon, M.T., Roden-Tice, M.K. and Carver, J.I. 1998. Late Cenozoic exhumation of the Cascadia accretionary wedge in the Olympic Mountains, northwest Washington State. Geological Society of America Bulletin, 110, 985-1009, https://doi.org/10.1130/0016-7606(1998)110<0985:LCEOTC $>2$. 3. $\mathrm{CO} ; 2$

Braun, J. 2002. Quantifying the effect of recent relief changes on age-elevation relationships. Earth and Planetary Science Letters, 200, 331-343, https://doi. org/10.1016/S0012-821X(02)00638-6

Braun, J., van der Beek, P. and Batt, G. 2006. Quantitative Thermochronology: Numerical Methods for the Interpretation of Thermochronological Data. Cambridge, Cambridge University Press.

Burbank, D.W. and Anderson, R.S. 2012. Tectonic Geomorphology, 2nd edn Wiley-Blackwell, Chichester, https://doi.org/10.1002/9781444345063

Carlier, G., Grandin, G., Laubacher, G., Marocco, R. and Mégard, F. 1982. Present knowledge of the magmatic evolution of the Eastern Cordillera of Peru. Earth-Science Reviews, 18, 253-283, https://doi.org/10.1016/00128252(82)90040-X

Carlier, G., Lorand, J.P., Bonhomme, M. and Carlotto, V. 1996. A reappraisal of the Cenozoic inner arc magmatism in southern Peru: consequences for the evolution of the central Andes for the past $50 \mathrm{Ma}$. In: Third International Symposium on Andean Geodynamics (ISAG). Saint Malo, 551-554.

Carlier, G., Lorand, J.P., Liégeois, J.P., Fornari, M., Soler, P., Carlotto, V. and Cárdenas, J. 2005. Potassic-ultrapotassic mafic rocks delineate two lithospheric mantle blocks beneath the southern Peruvian Altiplano. Geology, 33, 601-604, https://doi.org/10.1130/G21643.1

Dalmayrac, B., Laubacher, G. and Marocco, R. 1980. Géologie des Andes Péruviennes. ORSTOM, Paris.

Donelick, R.A., Sullivan, P.B.O. and Ketcham, R.A. 2005. Apatite Fission-Track Analysis. Mineralogical Society of America and Geochemical Society, Reviews in Mineralogy and Geochemistry, 58, 49-94, https://doi.org/10. 2138/rmg.2005.58.3

Ehlers, T.A., Chaudhri, T., Kumar, S., Fuller, C.W., Willett, S.D., Ketcham, R.A. and Brandon, M.T. 2005. Computational Tools for Low-Temperature Thermochronometer Interpretation. Mineralogical Society of America and Geochemical Society, Reviews in Mineralogy and Geochemistry, 58, 589-622, https://doi.org/10.2138/rmg.2005.58.22

Espurt, N., Baby, P. et al. 2007. How does the Nazca Ridge subduction influence the modern Amazonian foreland basin? Geology, 35, 515-518, https://doi.org/ 10.1130/G23237A.1

Espurt, N., Barbarand, J., Roddaz, M., Brusset, S., Baby, P., Saillard, M. and Hermoza, W. 2011. A scenario for late Neogene Andean shortening transfer in 
the Camisea Subandean zone (Peru, $12^{\circ} \mathrm{S}$ ): Implications for growth of the northern Andean Plateau. Geological Society of America Bulletin, 123, 2050-2068, https://doi.org/10.1130/B30165.1

Evans, N.J., Byrne, J.P., Keegan, J.T. and Dotter, L.E. 2005. Determination of Uranium and Thorium in Zircon, Apatite, and Fluorite: Application to Laser (U-Th)/He Thermochronology. Journal of Analytical Chemistry, 60, 1159-1165, https://doi.org/10.1007/s10809-005-0260-1

Farley, K.A. 2002. (U-Th)/He Dating: Techniques, Calibrations, and Applications. Mineralogical Society of America and Geochemical Society, Reviews in Mineralogy and Geochemistry, 47, 819-844, https://doi.org/10. 2138/rmg.2002.47.18

Fitzgerald, P.G. and Malusà, M.G. 2019. Concept of the Exhumed Partial Annealing (Retention) Zone and Age-Elevation Profiles in Thermochronology. In: Malusà, M.G. and Fitzgerald, P.G. (eds) FissionTrack Thermochronology and Its Application to Geology. Springer, Cham, 165-189, https://doi.org/https://doi.org/10.1007/978-3-319-89421-8 9

Flowers, R.M., Ketcham, R.A., Shuster, D.L. and Farley, K.A. 2009. Apatite (U$\mathrm{Th} / \mathrm{He}$ thermochronometry using a radiation damage accumulation and annealing model. Geochimica et Cosmochimica Acta, 73, 2347-2365, https:// doi.org/10.1016/j.gca.2009.01.015

Fox, N. and Bloom, A. 1994. Snowline Altitude and Climate in the Peruvian Andes $\left(5-17^{\circ} \mathrm{S}\right)$ at Present and during the Latest Pleistocene Glacial Maximum. Journal of Geography, 103, 867-885, https://doi.org/10.5026/ jgeography.103.7 867

Galbraith, R.F. and Laslett, G.M. 1993. Statistical models for mixed fission track ages. International Journal of Radiation Applications and Instrumentation. Part, 21, 459-470, https://doi.org/10.1016/1359-0189(93)90185-C

Gallagher, K. 2012. Transdimensional inverse thermal history modeling for quantitative thermochronology. Journal of Geophysical Research: Solid Earth, 117, 1-16. https://doi.org/10.1029/2011JB008825.

Garzione, C.N., Molnar, P., Libarkin, J.C. and MacFadden, B.J. 2006. Rapid late Miocene rise of the Bolivian Altiplano: Evidence for removal of mantle lithosphere. Earth and Planetary Science Letters, 241, 543-556, https://doi. org/10.1016/j.eps1.2005.11.026

Garzione, C.N., McQuarrie, N. et al. 2017. Tectonic Evolution of the Central Andean Plateau and Implications for the Growth of Plateaus. Annual Review of Earth and Planetary Sciences, 45, 529-559, https://doi.org/10.1146/annurevearth-063016-020612

Gautheron, C. and Tassan-Got, L. 2010. A Monte Carlo approach to diffusion applied to noble gas/helium thermochronology. Chemical Geology, 273, 212-224, https://doi.org/10.1016/j.chemgeo.2010.02.023

Gautheron, C., Tassan-Got, L., Barbarand, J. and Pagel, M. 2009. Effect of alphadamage annealing on apatite $(\mathrm{U}-\mathrm{Th}) / \mathrm{He}$ thermochronology. Chemical Geology, 266, 166-179, https://doi.org/10.1016/j.chemgeo.2009.06.001

Gautheron, C., Tassan-Got, L., Ketcham, R.A. and Dobson, K.J. 2012. Accounting for long alpha-particle stopping distances in (U-Th-Sm)/He geochronology: 3D modeling of diffusion, zoning, implantation, and abrasion. Geochimica et Cosmochimica Acta, 96, 44-56, https://doi.org/10.1016/j.gca. 2012.08.016

Gautheron, C., Espurt, N. et al. 2013. Direct dating of thick- and thin-skin thrusts in the Peruvian Subandean zone through apatite (U-Th)/He and fission track thermochronometry. Basin Research, 25, 419-435, https://doi.org/10.1111/ bre. 12012

Glotzbach, C., van der Beek, P.A. and Spiegel, C. 2011. Episodic exhumation and relief growth in the Mont Blanc massif, Western Alps from numerical modelling of thermochronology data. Earth and Planetary Science Letters, 304, 417-430, https://doi.org/10.1016/j.epsl.2011.02.020

Gonfiantini, R., Roche, M.-A., Olivry, J.-C., Fontes, J.-C. and Zuppi, G.M. 2001. The altitude effect on the isotopic composition of tropical rains. Chemical Geology, 147-167, https://doi.org/10.1016/S0009-2541(01)00279-0

Henry, S.G. and Pollack, H.N. 1988. Terrestrial heat flow above the Andean Subduction Zone in Bolivia and Peru. Journal of Geophysical Research: Solid Earth, 93, 15153-15162, https://doi.org/10.1029/JB093iB12p15153

Hoorn, C., Wesselingh, F.P. et al. 2010. Amazonia through time: Andean uplift, climate change, landscape evolution, and biodiversity. Science, 330, 927-931, https://doi.org/10.1126/science.1194585

Horton, B.K. 2005. Revised deformation history of the central Andes: Inferences from Cenozoic foredeep and intermontane basins of the Eastern Cordillera, Bolivia. Tectonics, 24, 1-18, https://doi.org/10.1029/2003TC001619

Hurford, A.J. and Green, P.F. 1983. The zeta age calibration of fission-track dating. Chemical Geology, 41, 285-317, https://doi.org/10.1016/S0009-2541 (83)80026-6

Husson, L. and Sempere, T. 2003. Thickening the Altiplano crust by gravitydriven crustal channel flow. Geophysical Research Letters, 30, 1-4, https:// doi.org/10.1029/2002GL016877

Insel, N., Poulsen, C.J. and Ehlers, T.A. 2010. Influence of the Andes Mountains on South American moisture transport, convection, and precipitation. Climate Dynamics, 35, 1477-1492, https://doi.org/10.1007/s00382-009-0637-1

Jaillard, E. and Soler, P. 1996. Cretaceous to early Paleogene tectonic evolution of the northern Central Andes $\left(0-18^{\circ} \mathrm{S}\right)$ and its relations to geodynamics. Tectonophysics, 259, 41-53, https://doi.org/10.1016/0040-1951(95)00107-7

Kennan, L. 2008. Fission track ages and sedimentary provenance studies in Peru, and their implications for Andean paleogeographic evolution, stratigraphy and hydrocarbon systems. In: VI INGEPET, 13-17 October 2008. Lima, Peru, 13.
Ketcham, R.A., Carter, A., Donelick, R.A., Barbarand, J. and Hurford, A.J. 2007 Improved modeling of fission-track annealing in apatite. American Mineralogist, 92, 799-810, https://doi.org/10.2138/am.2007.2281

Ketcham, R.A., Gautheron, C. and Tassan-Got, L. 2011. Accounting for long alpha-particle stopping distances in (U-Th-Sm)/He geochronology: Refinement of the baseline case. Geochimica et Cosmochimica Acta, 75, 7779-7791, https://doi.org/10.1016/j.gca.2011.10.011

Kirby, E. and Whipple, K.X. 2012. Expression of active tectonics in erosiona landscapes. Journal of Structural Geology, 44, 54-75, https://doi.org/10. 1016/j.jsg.2012.07.009

Kirby, E., Whipple, K.X., Tang, W. and Chen, Z. 2003. Distribution of active rock uplift along the eastern margin of the Tibetan Plateau: Inferences from bedrock channel longitudinal profiles. Journal of Geophysical Research: Solid Earth, 108, https://doi.org/10.1029/2001jb000861

Klein, A.G., Seltzer, G.O. and Isacks, B.L. 1999. Modern and last local glacial maximum snowlines in the Central Andes of Peru, Bolivia, and Northern Chile. Quaternary Science Reviews, 18, 63-84, https://doi.org/10.1016/ S0277-3791(98)00095-X

Lease, R.O. and Ehlers, T.A. 2013. Incision into the eastern Andean Plateau during Pliocene cooling. Science, 341, 774-776, https://doi.org/10.1126/ science. 1239132

Licciardi, J.M., Schaefer, J.M., Taggart, J.R. and Lund, D.C. 2009. Holocene glacier fluctuations in the Peruvian Andes indicate northern climate linkaqes. Science, 325, 1677-1679, https://doi.org/10.1126/science.1175010

Lindsay, J.B., Cockburn, J.M.H. and Russell, H.A.J. 2015. An integral image approach to performing multi-scale topographic position analysis. Geomorphology, 245, 51-61, https://doi.org/10.1016/j.geomorph.2015.05. 025

Mamani, M., Wörner, G. and Sempere, T. 2010. Geochemical variations in igneous rocks of the Central Andean orocline $\left(13^{\circ} \mathrm{S}\right.$ to $\left.18^{\circ} \mathrm{S}\right)$ : Tracing crustal thickening and magma generation through time and space. Geological Society of America Bulletin, 122, 162-182, https://doi.org/10. 1130/B26538.1

Mancktelow, N.S. and Grasemann, B. 1997. Time-dependent effects of heat advection and topography on cooling histories during erosion. Tectonophysics, 270, 167-195, https://doi.org/10.1016/S0040-1951(96 00279-X

Margirier, A., Robert, X., Audin, L., Gautheron, C., Bernet, M., Hall, S. and Simon-Labric, T. 2015. Slab flattening, magmatism, and surface uplift in the Cordillera Occidental (Northern Peru). Geology, 43, 1031-1034., https://doi. org/10.1130/G37061.1

Margirier, A., Audin, L., Robert, X., Herman, F., Ganne, J. and Schwartz, S. 2016. Time and mode of exhumation of the Cordillera Blanca batholith (Peruvian Andes). Journal of Geophysical Research: Solid Earth, 121, 6235-6249, https://doi.org/10.1002/2016JB013055

Marocco, R. 1971. Etude géologique de la chaîne andine au niveau de la déflexion d'Abancay (Pérou). Cahiers ORSTOM, 3, 45-58.

McQuarrie, N., Horton, B.K., Zandt, G., Beck, S. and DeCelles, P.G. 2005. Lithospheric evolution of the Andean fold-thrust belt, Bolivia, and the origin of the central Andean plateau. Tectonophysics, 399, 15-37, https://doi.org/10. 1016/j.tecto.2004.12.013

Mišković, A., Spikings, R.A., Chew, D.M., Košler, J., Ulianov, A. and Schaltegger, U. 2009. Tectonomagmatic evolution of Western Amazonia: Geochemical characterization and zircon $\mathrm{U}-\mathrm{Pb}$ geochronologic constraints from the Peruvian Eastern Cordilleran granitoids. Geological Society of America Bulletin, 121, 1298-1324, https://doi.org/10.1130/ B26488.1

Perez, N.D., Horton, B.K., McQuarrie, N., Stübner, K. and Ehlers, T.A. 2016. Andean shortening, inversion and exhumation associated with thin- and thickskinned deformation in southern Peru. Geological Magazine, 153, 1013-1041, https://doi.org/10.1017/S0016756816000121

Pérez-Gussinyé, M., Lowry, A.R., Phipps Morgan, J. and Tassara, A. 2008 Effective elastic thickness variations along the Andean margin and their relationship to subduction geometry. Geochemistry, Geophysics, Geosystems, 9, https://doi.org/10.1029/2007GC001786

Perron, J.T. and Royden, L. 2013. An integral approach to bedrock river profile analysis. Earth Surface Processes and Landforms, 38, 570-576, https://doi org/10.1002/esp. 3302

Picard, D., Sempere, T. and Plantard, O. 2008. Direction and timing of uplift propagation in the Peruvian Andes deduced from molecular phylogenetics of highland biotaxa. Earth and Planetary Science Letters, 271, 326-336, https:// doi.org/10.1016/j.epsl.2008.04.024

Poulsen, C.J., Ehlers, T.A. and Insel, N. 2010. Onset of Convective Rainfall During Gradual Late Miocene Rise of the Central Andes. Science, 328 490-494, https://doi.org/10.1126/science. 1185078

Recanati, A., Gautheron, C. et al. 2017. Helium trapping in apatite damage: Insights from (U-Th-Sm)/He dating of different granitoid lithologies. Chemical Geology, 470, 116-131, https://doi.org/10.1016/j.chemgeo.2017. 09.002

Reiners, P.W. and Brandon, M.T. 2006. Using Thermochronology To Understand Orogenic Erosion. Annual Review of Earth and Planetary Sciences, 34 419-466, https://doi.org/10.1146/annurev.earth.34.031405.125202

Reiners, P.W. and Shuster, D.L. 2009. Thermochronology and landscape evolution. Physics Today, 31-36, https://doi.org/10.1063/1.3226750 
Reuter, H.I., Nelson, A. and Jarvis, A. 2007. An evaluation of void-filling interpolation methods for SRTM data. International Journal of Geographical Information Science, 21, 983-1008, https://doi.org/10.1080/ 13658810601169899

Rizzoli, P., Martone, M. et al. 2017. Generation and performance assessment of the global TanDEM-X digital elevation model. ISPRS Journal of Photogrammetry and Remote Sensing, 132, 119-139, https://doi.org/10. 1016/j.isprsjprs.2017.08.008

Roperch, P., Carlotto, V., Ruffet, G. and Fornari, M. 2011. Tectonic rotations and transcurrent deformation south of the Abancay deflection in the Andes of southern Peru. Tectonics, 30, https://doi.org/10.1029/2010TC002725

Ruiz, G.M.H., Carlotto, V., Van Heiningen, P.V. and Andriessen, P.A.M. 2009. Steady-state exhumation pattern in the Central Andes - SE Peru. Geological Society, London, Special Publications, 324, 307-316, https://doi.org/10.1144/ SP324.20

Schildgen, T.F. and Hoke, G.D. 2018. The topographic evolution of the central Andes. Elements, 14, 231-236, https://doi.org/10.2138/gselements. 14.4.231

Schwanghart, W. and Scherler, D. 2014. TopoToolbox 2 - MATLAB-based software for topographic analysis and modeling in Earth surface sciences. Earth Surface Dynamics, 2, 1-7, https://doi.org/10.5194/esurf-2-1-2014

Schwarz, G.E. 1978. Estimating the dimension of a model. Annals of Statistics, 6, 461-464, https://doi.org/10.1214/aos/1176344136

Strecker, M.R., Alonso, R.N., Bookhagen, B., Carrapa, B., Hilley, G.E., Sobel, E.R. and Trauth, M.H. 2007. Tectonics and Climate of the Southern Central Andes. Annual Review of Earth and Planetary Sciences, 35, 747-787, https:// doi.org/10.1146/annurev.earth.35.031306.140158

Stüwe, K., White, L. and Brown, R. 1994. The influence of eroding topography on steady-state isotherms. Application to fission track analysis. Earth and Planetary Science Letters, 124, 63-74, https://doi.org/10.1016/0012-821X(94)00068-9

Sundell, K.E., Saylor, J.E., Lapen, T.J. and Horton, B.K. 2019. Implications of variable late Cenozoic surface uplift across the Peruvian central Andes. Scientific Reports, 9, 1-12, https://doi.org/10.1038/s41598-019-41257-3

Sundell, K.E., Saylor, J.E., Lapen, T.J., Styron, R.H., Villarreal, D.P., Usnayo, P. and Cárdenas, J. 2018. Peruvian Altiplano Stratigraphy Highlights
Along-Strike Variability in Foreland Basin Evolution of the Cenozoic Central Andes. Tectonics, 37, 1876-1904, https://doi.org/10.1029/ 2017TC004775

Uba, C.E., Strecker, M.R. and Schmitt, A.K. 2007. Increased sediment accumulation rates and climatic forcing in the central Andes during the late Miocene. Geology, 35, 979-982, https://doi.org/10.1130/G224025A.1

Wagner, G., Reimer, G. and Jäger, E. 1977. Cooling ages derived by apatite fission track, mica $\mathrm{Rb}-\mathrm{Sr}$ and $\mathrm{K}$-Ar dating: the uplift and cooling history of the central Alps. Memorie degli Istituti di Geologia e Mineralogia dell'Università di Padova, 30, 1-27.

Whipple, K.X., Forte, A.M., DiBiase, R.A., Gasparini, N.M. and Ouimet, W.B. 2017. Timescales of landscape response to divide migration and drainage capture: Implications for the role of divide mobility in landscape evolution. Journal of Geophysical Research: Earth Surface, 122, 248-273, https://doi. org/10.1002/2016JF003973

Willett, S.D., McCoy, S.W., Perron, J., Goren, L. and Chen, C.Y. 2014. Dynamic reorganization of River Basins. Science, 343, https://doi.org/10.1126/science. 1248765

Wise, J.M. and Noble, D.C. 2008. Late Pliocene inception of external drainage and erosion of intermontane basins in the highlands of Central Perú. Revista de la Sociedad Geológica de España, 21, 73-91.

Wobus, C.W., Hodges, K. and Whipple, K. 2003. Has focused denudation at the Himalayan topographic front sustained active thrusting near the Main Central Thrust? Geology, 31, 861-864, https://doi.org/10.1130/G19730.1

Wobus, C., Whipple, K.X. et al. 2006. Tectonics from topography: Procedures, promise, and pitfalls. Geological Society of America, Special Papers, 398, 55-74, https://doi.org/10.1130/2006.2398(04)

Zeilinger, G. and Schlunegger, F. 2007. Possible flexural accommodation on the eastern edge of the Altiplano in relation to focused erosion in the Rio La Paz drainage system. Terra Nova, 19, 373-380, https://doi.org/10.1111/j.13653121.2007.00762.x

Zhang, P., Molnar, P. and Downs, W.R. 2001. Increased sedimentation rates and grain sizes 2-4 Ma ago due to the influence of climate change on erosion rates. Nature, 410, 891-897, https://doi.org/10.1038/35073504 